\title{
Educational Reform as Innovation Diffusion: Development of a Theory and Test of a Model Using Continuing Professional Development and Instructional Technology
}

\author{
Michael Szabo \\ University of Alberta, Edmonton, Canada
}

mike.szabo@ualberta.ca

\begin{abstract}
Lack of implementation of instructional technology either to improve the classroom or to reform educational practice stimulated a study of the diffusion of innovation, which in turn led to creation of a new theory of reform through IT. This was followed by development of a model to test the theory. This paper describes the theory, the model and evaluative results from implementing the model. The major conclusion from this exercise is that research-oriented universities may underestimate the magnitude of the disruptive, second-order reform nature of IT. Consequently, they are likely to apply inappropriate change strategies instead of looking to the guidance from the history of innovation diffusion.
\end{abstract}

Keywords: Innovation, Diffusion, Professional Development, Reform, Technology

\section{Overview}

The big story in the field of information technology for education and training is not what marvelous new technology we educators now have available at our fingertips. The big story is the slow takeup of this technology and the challenge this poses for educational managers.--Mitchell, 1992

We are engaged in a communication technology revolution involving digitally-based instruction and training called instructional technology (IT). Although IT has been around for nearly four decades, it has not as yet made major inroads in the process of educational change and reform. The author argues this is the result of inappropriate application of processes of change and reform. A study of the history of innovation diffusion led to a new theory of change which assumes that IT is a sophisticated, second-order innovation (Moller, 1993) and lessons from the diffusion of innovation must be understood as a precondition to bringing about significant reform. Part I of this paper presents this theory of change as distilled from a history of innovation diffusion. Part II documents a working model (The Training, Infrastructure and Empowerment System, or TIES), based on this new innovation diffusion theory for reform in post secondary education. Part III describes TIES implementation at a major research university and results obtained from a qualitative research study.

Modern society is experiencing several converging forces: 1) the information communications technology

Material published as part of these proceedings, either on-line or in print, is copyrighted by Informing Science. Permission to make digital or paper copy of part or all of these works for personal or classroom use is granted without fee provided that the copies are not made or distributed for profit or commercial advantage AND that copies 1) bear this notice in full and 2) give the full citation on the first page. It is permissible to abstract these works so long as credit is given. To copy in all other cases or to republish or to post on a server or to redistribute to lists requires specific permission from the publisher at Publisher@InformingScience.org
(ICTR) revolution and its related offspring, the instructional technology (IT) revolution, 2) the trend toward a service economy from a manufacturing economy and 3) the increased need for education and training.

The traditional approach to meeting increased training and education needs demands massive investments in human resources. However, developing 
countries are unable to afford even basic education for the majority of their populations, and developed countries are busy trying to place a spending cap on labor-intensive industries or to divest entirely through privatization. IT is being investigated to meet those needs, bolstered by gains in productivity from ICTR and the studies which have shown that IT is a contributing factor in increasing: 1) achievement and attitude, 2) access to learning opportunities, and 3) learning efficiencies, compared with instruction which does not use IT (Szabo, 2000).

Seventy percent of the more than 4,000 two- and four-year U.S. colleges provided at least one online course last year, a 22 percent rise from 1998; web based e-learning is the most common form of distance and lifelong education. In the US, the postsecondary online market is estimated at $\$ 1.2$ billion, expected to grow to $\$ 7 \mathrm{~B}$ by 2003 . US corporate e-learning market is estimated at $\$ 1.1 \mathrm{~B}$, expected to grow to $\$ 11.4$ B by 2003 . The global market is estimated at $\$ 300 \mathrm{~B}$ to grow to $\$ 365$ B by 2003 (U.S. Department of Education, 2000).

Despite a huge investment by American higher education in the past 15 years (Green, 2000), a relatively small percentage of faculties have embedded instructional technology into their curriculum. Numerous technologies from television to multimedia which have been hailed as tools to revolutionize education; all have fallen far short of those promises. Still fewer have experienced educational reforms, that is made major purposive changes through IT.

The author has observed major changes in hardware, software, courseware, communications, people, and learning theories during his three decades in the field of IT. But there are two trends, which have remained unchanged. First, the number of educators who use instructional technology courseware has not risen above the 20 percent level expected of innovators and early adopters found in any organization (Rogers, 1995). Second, education continues to elude major changes or restructuring of educational practice related to instructional technology. The dominant mode of instruction today continues to be the selfcontained classroom in which one instructor meets face to face with a group of learners and engages heavily in CHAI (chalkboard assisted instruction).

IT is being used quite sparingly in education and to date has had little impact on catalyzing the reforms needed to make further headway in meeting the learning needs of society. Why is progress in this area so slow? Monies have been allocated worldwide for infrastructure creation and personnel training.

TIES is founded on the assumption that the lack of significant progress is caused by failure to apply a valid theory of change and reform.

TIES began with a review of change theories and a history of the diffusion of innovation leading to the development of a new theory of reform, the TIES Reform Theory (TRT) that was employed to create a system of reform (i.e., TIES) to adopt IT in a research university. The change system was piloted and evaluation data gathered which sought to inform the theory as well as the system.

In summary, there are four key assumptions on which this project is based: 1) education and training are increasingly important to developing and developed societies and can and should be improved, 2) a radical restructuring is advocated rather than a system of minor adjustments, 3) (IT), with its deep links to the ICT revolution, can play a major part in this revolution, and 4) a theory of reform based on the diffusion of innovation can provide a solid basis from which to launch and sustain this revolution.

\section{Problem Statement}

We live in a transitory period between an industrial society, where schools evolved to prepare people for the industrial society, and an information society. What should schools look like in order to prepare society for the information society, and how do we make the transition? 


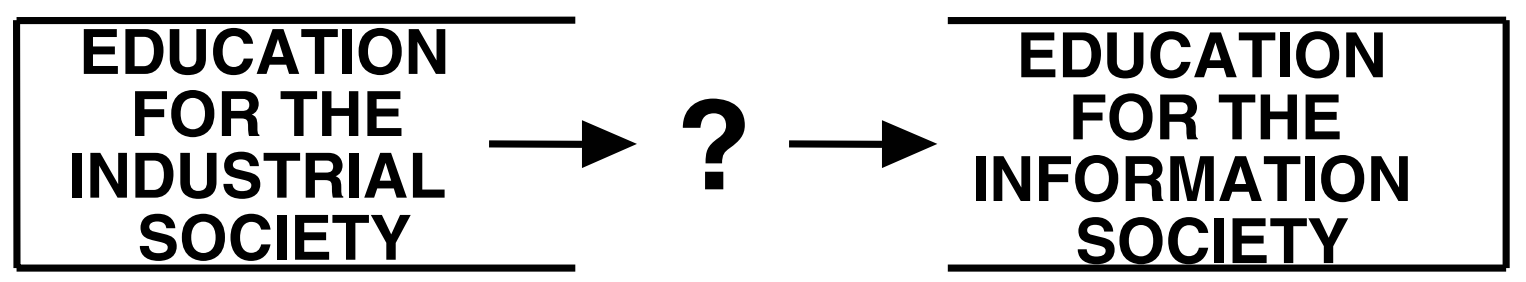

It is the author's contention that most attempts at reform through IT fail because the emphasis is placed on easily quantified factors such as money spent, infrastructure and skills training, at the expense difficult and unquantifiable processes that deal with change per se. More specifically, this work is based on the premises that IT is a disruptive and innovative technology and any reform attempts will not succeed unless they pay significant homage to the process of changing peoples' behaviors as a major component of the effort.

\section{Peoples' Behavior is Hard to Change}

Etzioni observed, "We are now confronting the uncomfortable possibility that human beings are not very easily changed after all.” (Etzioni, 1972, p 45). He went on to state

The contention that personal growth and societal changes are much harder to come by than we had assumed, especially via one version or another of the educationalist-enlightenment approach, is not a joyful message, but one whose full implications we must learn to accept before we can devise more effective social programs. (Etzioni, 1972, p 47).

Countless reform efforts are built on the theme "Build it and they will come," a successful movie theme but largely a myth. Over-zealous proponents of innovation who, without a grasp of history, have made inaccurate and misleading predictions about the impact of innovations, leading to widespread disillusionment. Individuals and institutions have a natural and rational reaction to anything disruptive and innovative: they resist it in order to preserve the comfortable systems they worked so long and hard to build. Rossman, Corbett and Firestone (1988) observe that adults are experts at pretending reform is taking place without vesting any ownership in the process, especially when there are implicit sanctions against changing. Conventional approaches to reform ignore the important aspects of reform of human behavior in professional development.

\section{Educators' Behavior is Hard to Change}

"But why do so many of the promising and highly touted [education] innovations fade into obscurity or later face ridicule?" (Alexander, Murphy \& Woods, 1996, p. 31). While most innovators pursue change for valid reasons, not simply for the sake of change (Smith, Kleine, Prunty, \& Dwyer, 1986), most reforms fail to achieve their goals (Goodlad, 1984; Leithwood \& Montgomery, 1982). In some cases, reform fails due to major social change (Smith, et al., 1986). Presseisen (1985) analyzed eight widely publicized programs created to address (American) educational problems (Allen, 1992; Coombs, 1985; Finn, 1991; NCOEIE, 1983). She concluded none of them proposed any serious innovation, simply adjustments to the current way of doing things. School districts undertake innovation under circumstances of unclear goals, unpredictable technology, and uncertainty in general (Morris, 1997). Reform in education is as problematic as reform in other fields.

\section{Instructional Technology Reform in Particular}

Prominent leaders in the field of IT and school reform have offered their observation- and research-based opinions: 
This persistent dream of technology driving school and classroom changes has continually foundered in transforming teaching practices. Although teachers have slowly added a few technologies to their repertoires, techno-reformers have seldom been pleased with either the pace of classroom change or the ways that teachers have used new machines...patterns of teacher use similar to those that accompanied earlier technologies billed as revolutionary seem to be recurring: a small cadre of determined users amid a large majority of casual and nonusers. (Cuban, 1996).

Until we reform our conceptions of learning, technologies will continue to be delivery vehicles and not tools to think with. In that capacity, they will have little substantive effect on education, as has been the case for most of the history of our field. That would be unfortunate, since as tools, context, and intellectual partner, technologies can indeed revolutionize education. (Jonassen, 1995, p 61).

In US public schools, the spending on technology amounts to no more than $\$ 175$ per student per year, mostly for hardware and infrastructure, relatively little for software and technology support. However, teacher-directed student use of computers during class and perceptions of the effects computers have had on their classes are more a function of the school's software than the installed hardware base (Anderson \& Becker, 2001).

Technology is not the primary consideration in the innovation process, rather the matching of the social context, people, technology, and purposive action make the innovation. Deal, Meyer \& Scott (1975) found organizational autonomy, decentralized authority, staff professionalism, and features of organizational climate such as openness, trust, and free communication to be correlates of innovative behavior.

\section{Educational Reform and Innovation Theories}

There are few models of reform based on disruptive innovations. This paper puts forward a new theory of reform, based on an examination of the offerings of prominent reform advocates such as Ernst \& Young (2000), Fullan (1991), Kotter (1996), Lewin (1952), Moller (1993), Mullock (2001), Odomirok (2001), Orlikowksi \& Hofman (1997), Rogers (1995), Senge (1990), Sink \& Morris (1995). Theories emanated a variety of domains, not just education. The review expanded to include a study of the history of innovation, e.g., Hughes, 2001; Mosteller, 1981.

From this work, a picture of what faces the would-be reformer begins to emerge. What seems to be lacking is a strong theoretical sense of what makes for a successful diffusion of a disruptive innovation, along with a reasoned application of the theory which may be summoned to test it.

\section{What Influences Reform? Lessons Learned from Innovation Diffusion History}

This section reviews characteristics of innovation, some of which are in opposition to conventional wisdom. Implications for a theory of reform through IT follows.

\section{Technological Innovations Spawn Sociotechnological Systems}

Almost every major revolution to impact humankind has technological roots: the steam engine, printing press, computer, and so forth. It is easy to overlook the fact that technology spawns complex social systems which have as much influence on diffusion of the innovation as the innovation itself (Hughes, 2001). It is the matching of the social context, people, technology, and purposive action that make the change and reform (Crawford \& Strohkirch, 1997; Postman, 1983). Hughes observed: 
History suggests that everything will change in unanticipated ways. In the 1920's a number of researchers from different fields believed they were experiencing a sociotechnological revolution, but wrongly believed that new technical systems would drive social changes. Technology is malleable, that is it is shaped by social values, often directed by those with different agendas for new technologies... (Hughes, 2001, p. 19).

Innovation diffusion with respect to IT has two components: the technological and the sociotechnological. The latter is the most crucial to get right but is most likely to be ignored.

\section{Innovation Diffusion is Driven by Vision}

"As for the Future, your task is not to foresee, but to enable it." Antoine de Saint-Exupéry, 1979).

The diffusion of innovations follows circuitous, unpredictable paths. In the absence of roadmaps, innovations are often guided by a highly dedicated individual with a strong vision of the future, unflagging dedication to achieving that vision and the ability to motivate others to actualize that vision. Often the innovation is given form and shape by teams of individuals who share the vision (Senge, 1990) and are empowered to bring the vision into reality.

\section{Innovation Diffusion is Poorly Understood}

Moller (1993) draws a useful distinction between changes that do not affect the basic structure of an organization and those that do. He calls the latter "second-order" change (reform) and states they require a paradigm shift in the culture of the organization. A central thesis of this paper is that IT is a second-order change. Diffusion approaches used in simple "first-order" change will not work in disruptive, "secondorder" reform. Morris (1997) observed that instructional innovations are likely to be restricted to imitations of others or of revisions of past technologies, repackaged by academics within or closely associated with the field of education.

\section{Innovation Diffusion is Rarely Successful}

Fewer innovations than we think become widely (i.e., successfully) diffused. Mosteller studied technological innovations and concluded "...we find again that when innovations are put to trial, they are successes only about half the time, and that substantial improvements are relatively rare, about one in seven." (1981, p. 883). Murgatroyd in Thompson (2001) pointed out that thirty six percent of all information technology projects fail.

Cuban generously observed, "...each technological innovation has had, at best, an uneven record in entering [public education] schools and classrooms." Schools have rejected or altered technologies that have been announced as revolutionary and transformative, extending as far back to the introduction of Thomas Edison's film projector in the 1910s, and including radio and television (Cuban, 1986). O'Neil, (1995, p. 7) commented, less kindly "The graveyard of school reform is littered with technological innovations that failed to live up to their advance billing."

\section{Innovation Diffusion Takes Longer than We Believe}

The elapsed time between an innovations' development and its widespread adoption is called the innovation diffusion gap (IDG). An IDG of 264 years from discovery of how to prevent scurvy to wiping it out in the British maritime trade took a terrible toll in human lives (Mosteller, 1981). One hundred and fifty years after the development of a simple pump in a Scottish mine, the industrial revolution finally became widespread in many forms around the world. A patent for the forerunner of the modern fax machine was issued in the 1840s. The laser and mouse took about 20 years from invention to widespread application. "It took education more than 300 years to fully take advantage of the technological revolution in movable 
type. And it was almost 100 years between the invention of the pencil and its wide use in schools..." (Lockard, Abrams, \& Many, 1997, p. 373).

The IDG is significantly longer than most people are willing to acknowledge. This makes it easier to forget a most valuable and intractable lesson.

\section{Innovations Undergo Radical Changes During Their Lifetimes}

'He who predicts the future is a liar, even if he is telling the truth' states an old proverb. The ultimate uses for innovations are often quite different and unexpected compared with the vision of the developer. It is unlikely the Wright brothers imagined a 747 carrying hundreds of passengers. Alexander Graham Bell had a vision for creating a tool for the deaf that turned out to be the telephone. The Internet was designed as a closed, secure system for national security during the cold war in the 1960s but continues to evolve into something quite different today, open and operated by many.

Teachers do use innovations but adapt differently according to the needs of students (Spencer, 1996). Tyack and Cuban (1995) proposed that innovations be designed to be open to modification by those who must implement them. People are more likely to support and enhance goals and innovative methods which they are empowered to create or control, as opposed to those imposed by outside.

\section{Innovation Diffusion Cannot be Managed}

Goals for reform 'handed down from on high' do not accommodate the unique needs, characteristics, politics, and personalities of individual departments as they deal with second-order change. As such, they are suspect, quickly discredited or ignored to suffer a quiet but ignominious death. Cuban (1996) speaks of techno-reformers.

To techno-reformers the answer is simple: Teachers lack the access, knowledge, and skills to use these machines properly. When teachers are thus blamed, solutions also become obvious: Provide teachers with sufficient computer hardware and software, technical assistance in using the machines, and better preparation programs. Technology-leaning policymakers, corporate leaders, and other influential noneducators, with their access to media, have framed both the problem and the solution. Teachers, then and now, remain voiceless in setting the reform agenda.

Imposing a standard way to do something runs the risk of shutting down would-be innovators' ability to think of new approaches (Shalley \& Perry-Smith, 2001). It has been asserted that innovation must be led; it cannot be managed (Kotter, 1996; Senge, 1990). The process of innovation is messy and a strong, centralized organizational structure with controls designed to maintain organizational stability provides infertile ground to grow innovation. The improvisation model of change management, alternatively, suggests that "rather than predefining each step and then controlling events to fit the plan, management creates an environment that facilitates improvisation." (Orlikowsky \& Hofman, 1997, p. 20).

\section{Innovation Diffusion Involves Trial, Error and Risk Taking}

Most campuses have IT development programs ( 75.8 percent) and campus support centers (65.9 percent) to assist faculty in bringing technology resources into their courses. However, just one-seventh (13.7 percent) of colleges and universities have a formal, institutional program to recognize and reward the use of information technology as part of the faculty review process. The 1999 data show little change on these measures over the past few years (Green, 1999). 
R \& D proceeds as an iterative combination of empirical testing and science application (Hughes, 2001). While science texts glowingly inform us of the progress that has been made, they fail to reveal the litter heaps of theory, model and application testing which had to be discarded. Diffusion entails significant individual and institutional risk because it involves creating and testing new ideas and discarding those that don't work. Very few organizations or supervisors will tolerate risk (Pinchot, 1985).

\section{Innovation Diffusion Progresses Through Well-Defined Stages}

Innovation diffusion is characterized by passage of individuals and institutions through three stages. First, people 'play' with it, to find out its capabilities and limitations. In the second stage, they use the technology to assist them in their daily chores and responsibilities. In the third stage, they begin to use the innovation to help address new opportunities or problems which have not been addressed before the innovation, problems previously though unassailable.

Dooley (1999) summarized the concerns theory of Hord:

At the beginning of a change process, the typical "non-user" has concerns that are relatively high in Awareness, Information, and Personal (self concerns). Non-users or low users are more concerned about gaining information about the innovation and about how change will affect them personally. As they begin to use the new program or innovation, concerns become more intense in the area of Management (task concerns). As a teacher becomes more experienced and skilled with an innovation, the tendency is for concerns at the lower stages to decrease in intensity while those in higher stages such as Consequence, Collaboration, and Refocusing become more intense (impact concerns).

\section{Successful Innovation Diffusion is Hard to Define}

Innovation is successfully diffused when it is used by large numbers of people making fundamental changes in the way they conduct their activities or enterprises. Critical mass theory gives some guidelines for decision making about continued investment of time and resources. (Rogers, 1995; Markus, 1990; Oliver, Marwell, \& Teixeira, 1985). Markus (1990) has argued that critical mass must include institutional, faculty and student access. David \& Wright (1999) suggest a technology will have a significant effect on productivity when it has reached a $50 \%$ diffusion rate.

\section{Resistance to Diffusion is Natural}

\section{P. Snow (1961) lamented}

In a society like ours, academic patterns change more slowly than any others. In my lifetime, in England, they have crystallized rather than loosened. I used to think that it would be about as hard to change, say, the Oxford and Cambridge scholarship examination as to conduct a major revolution. I now believe that I was over-optimistic.

History abounds with instances of errors in judgment about innovations becoming successfully diffused into society. Consider this 1959 prediction: "Ball point pens will be the ruin of education in our country. Students use these devices and then throw them away! The American virtues of thrift and frugality are being discarded. Business and banks will never allow such expensive luxuries." (White, 2001).

If a threat to the existing power structure is perceived, resistance may take the form of vested interests dominating.

Technology is malleable, that is it is shaped by social values, often directed by those with different agendas for new technologies, e.g., some with a stake in preserving the status quo and opposing activities which threaten to diminish their power base ... Most college and 
Educational Reform as Innovation Diffusion

university administrators and some faculty envisage a technology--enabled education that reinforces their visions and vested interests. (Hughes, 2001, p. 19).

\section{Implications from Innovation Diffusion Studies}

From this study, the author identified several characteristics which seem to appear repeatedly in numerous reports of diffusion of innovations. These characteristics give rise to several directions to consider in attempting to deal with second-order, complex reform.

1. Diffusion involves a significant innovation diffusion gap, the elapsed time between the development of an innovative process or product and its widespread adoption. The innovation diffusion gap is regularly often grossly underestimated, and does not fit within the limited appointment time of most administrators.

2. The majority of innovations fail to survive. Innovation is at odds with good stewardship, the preservation of the institution for the good of all.

3. Innovation diffusion is difficult or impossible to manage using conventional administrative tools. Innovation diffusion can't be managed-it must be led. Allow for new systems to evolve, free from conventional administrative restrictions, and formulate policy to support the new systems. Develop strategies to maintain the best of the old while building the new.

4. People and institutions play, use and create, three identifiable stages, when they encounter an innovation-Provide resources, guidance and evaluation commensurate with the current stage which the individual and institution find themselves.

5. Technological innovations spawn complex and changing sociotechnological systems. Diffusion must plan to deal with both, probably on an equal footing.

6. Because innovations follow circuitous, unpredictable paths, and there are few roadmaps, they are often guided by a strong, shared and clear vision of the future. A strong and shared vision of the future of an innovation precedes successful innovation diffusion. Successful diffusion is dependent upon recruiting the visionary personalities.

7. Accepted as an abstract concept, rejected as an operational outcome (the rational behavior of individuals and institutions is to promote stability and resist change). Individuals and institutions must assign innovation diffusion the significant role (second-order) it deserves, over and above simple change, and act accordingly.

8. Innovation diffusion can be unfairly associated with failure. It involves testing many ideas/approaches and discarding, through trial and error, those that don't work. A supportive atmosphere of creativity, risktaking, trial-and-error and appropriate reward structures need to be created to sustain the lengthy diffusion process.

9. Many innovations undergo radical changes from their original intentions, under local control. At the local level, individuals need to have the power to influence how the innovation is used in their sphere of interest.

10. Resistance to innovation diffusion is a normal, natural and rational response. Understand the leadership skills needed to help people and institutions change this response.

11. Successful innovation diffusion is hard to define. The notion of critical mass should be invoked to ascertain when successful diffusion has occurred. Unconventional methods need to be considered to reach the critical mass. 


\section{A New Approach to Reform Through IT and Professional Development}

It must be remembered that there is nothing more difficult to plan, more doubtful of success, nor more dangerous to manage than the creation of a new system. For the initiator has the enmity of all who would profit by the preservation of the old institution and merely lukewarm defenders in those who would gain by the new ones. --Machiavelli, 1513

Consideration of the characteristics of reform resulted in several principles that are likely to maximize the chances of successful adoption of the IT innovation. These principles form the basis of a new theory of reform: the TIES Reform Theory (TRT).

1. Reform requires significant attention to the sociotechnological system that grows up around a technical innovation, such as IT.

2. Renewal cannot be separated from professional development of our major resource-the intellectual capability and leadership of our personnel.

3. People most affected by the renewal must be empowered to make the decisions and generate the direction the renewal proceeds.

4. Renewal is driven by the development of a mutually shared vision of a future.

5. Renewal requires commitment and sacrifices that should be visibly embraced by all affected.

6. Renewal involves taking risks and taking risks involves making mistakes; people should be encouraged to take calculated risks, certainly not penalized.

7. Renewal must be concentrated in areas where there is maximum leverage and conventional methods for diffusion must be questioned and replaced as necessary.

8. Management and administrative style must adapt from dealing with first-order change to secondorder change.

\section{The Training Infrastructure and Empowerment System (TIES)}

The purpose of TIES was to design and test a system for change in a university environment based on the TIES Reform Theory. There are two major components in TIES. First is the establishment of a shared vision and commitment to it from the Chief Academic Officers (CAO). The second is the creation of a system based on continuing professional leadership development to empower faculty to turn the vision into a reality (Szabo, Anderson, \& Fuchs, 1998).

\section{Vision}

In keeping with the need for a guiding vision, $\mathrm{CAO}$ create a vision and ways to overcome the barriers, ways to communicate the vision and their commitment to the whole university community and ways to show their commitment to that vision.

\section{Empowerment to actualize the vision}




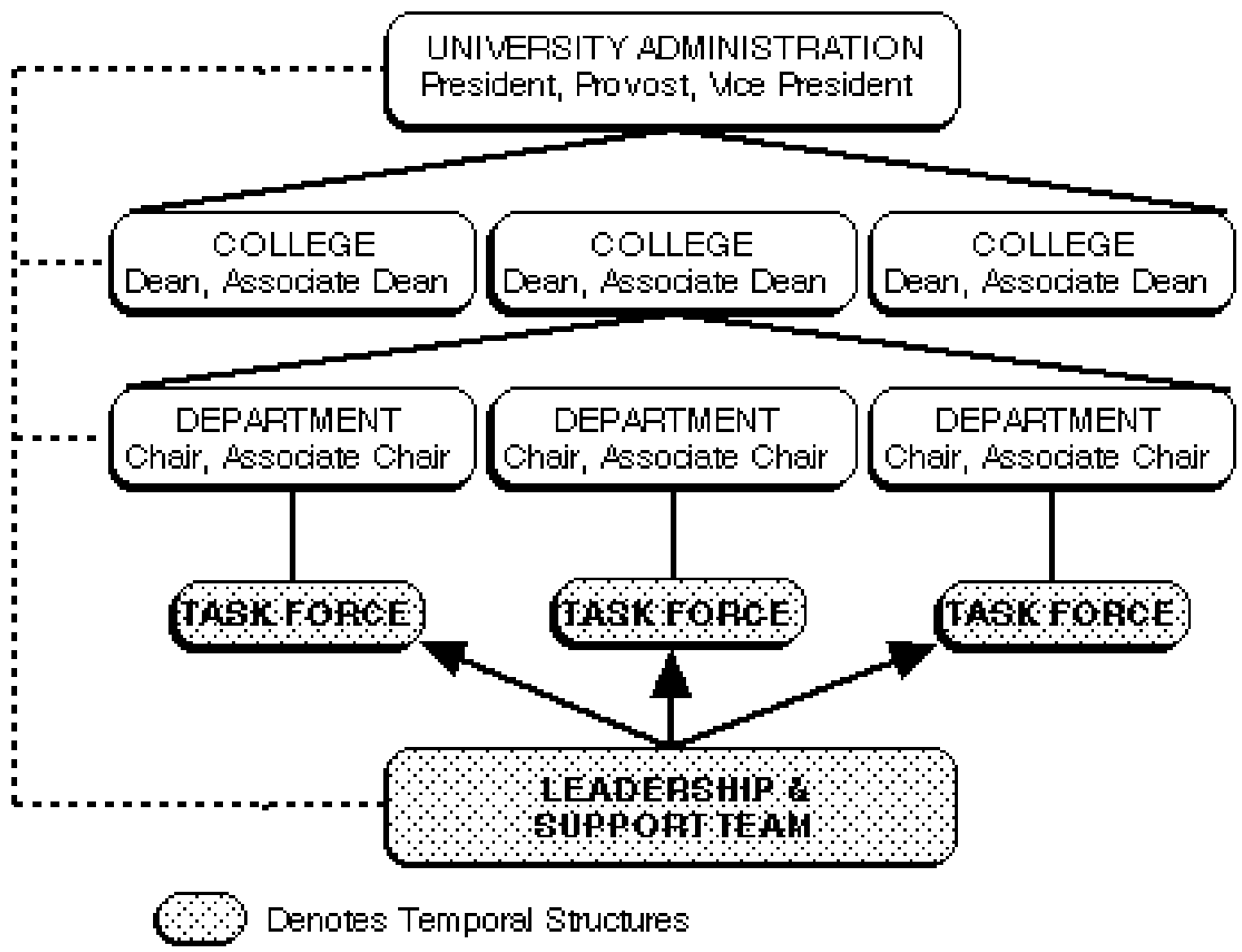

Figure 1 Organizational Structure of the TIES Leadership Task Forces

The second component of TIES is to empower and leverage department-level faculty and administrators to actualize the vision in their local sphere of work through the creation, training, empowerment and support of department-based TIES Leadership Task Forces (TLTF)s. Figure 1 illustrates this organizational structure.

Expectations for the TLTFs include: 1) operate at the Department level for strategic leverage, since most decisions are made at that level, 2) create department-based TLTFs which include opinion leaders plus departmental administrators, 3) provide training (see below), support and resources to TLTFs to prepare them to a) become credible users of IT, b) systematically train departmental colleagues, d) support departmental colleagues using just-in-time principles, and d) create long-range plans for the department to carry out the shared vision in their department, and 4) upon completion of their work, TLTF members return to their job assignments, thereby building the expertise at the department level for a legacy effect.

TLTFs were prepared for their work in a workshop format whose goals were to facilitate team-building skills and insure that minimum competencies were present in each team. Training incorporated the best of adult learning principles and was rich in resources, including a series of Web-based training modules (Szabo, 1998). The modules developed competencies in hard and soft skills, interactive and distance technology, application of IT to curriculum, instruction and evaluation and perhaps most important, leadership skills. The Continuing Professional Leadership Development Modules consist of: 1) Developing \& Sharing A Vision for Alternative Delivery Systems, 2) Working with Teams \& the Task Force Approach, 3) Dealing with Mental Models, 4) Selling Your Ideas (Seek first to understand), 5) The Promise and Pitfalls of Innovation: Understanding Organizational Stability, 6) Importance of Training and Continuous, Accessible Support, 7) Long Range (Multi-Year) Planning, and 8) Reporting Project Progress. 


\section{TIES Findings}

\section{Creating the Shared Vision}

The first step was to garner support for the complex and unusual idea of using an unconventional model based on innovation and professional leadership development to promote reform.

During a retreat with CAO in December 1997, limited progress was made toward creating a vision for the university. One key outcome was to begin a dialogue on the role of IT with the deans of the university. Upon return to campus, continued work on a vision for reform seems to have given way to more pressing issues within the institution. Another subsequent outcome was the development of an updated version of the institution's technology integration plan. In spite of the absence of a shared vision to give direction to departments, it was decided to proceed with the second component, leadership training.

\section{TIES Leadership Task Forces}

After numerous clarification meetings, five TLTFs were identified. Three were based within faculties rather than departments, due to their small size. The TLTF training took place during a 4-day break in February 1998.

The entire TLTF A participated, including the department chair and a faculty member who was officially on sabbatical leave. They worked enthusiastically on the training, the discussion group activities, and discussed how they could optimize their impact on the rest of the department. They also finalized their long-range plans which had been under development for some time prior to the TIES workshop.

TLTF B, on the other hand, was a no-show. No one from the team participated and the chair did not offer the courtesy of contacting the workshop coordinators that they had decided not to participate. The author concluded that the high need expressed for the program by the chair of this department did not translate into action and IT and/or reform was not sufficiently high in importance.

TLTF C initially consisted of a single individual who had recently returned to his faculty from several years at another institution. This individual was well versed in the WWW component of IT and keenly interested in promoting IT in general. The Dean of this Faculty specifically requested a TLTF and the individual had experienced in another university a plan for IT that had been imposed upon the faculty without consultation and with counterproductive results. The TIES presented quite a contrast in methodology. The participation was enthusiastic and subsequently this individual was reassigned to a full time position to provide IT leadership, formed a team, and proceeded to integrate IT into his faculty.

TLTF D did not translate the specified team structure into reality. It consisted of one full time faculty member who was actively developing a WWW course for the faculty, three part time sessional instructors, and no faculty administrators. The sessionals attended only 1-2 days of the workshop. The faculty member participated on a part time basis, so there was no real task force developed from this faculty. The follow up activity by this group was to create a series of IT-training programs for the faculty using Power Point, continued WWW development and participated in a faculty-based IT committee.

TLTF E was at the faculty level and consisted of a seasoned IT person, also just returned from a sabbatical leave, an Associate Dean, and a sessional instructor. They participated in the entire workshop and developed ideas for working with their colleagues.

From February 1998 through June 1999, the central leadership team maintained contact with the TLTFs for one year through normal communications means plus a web conferencing system. 


\section{Interviews with Stakeholders}

In 2000-2001, interviews were conducted with four original stakeholder groups involved in TIES; two chief academic officers (CAO), two project directors (PD), four faculty/department administrators (F/DA) and four faculty members (FM). This case study analysis used inductive content analysis, verified by triangulation including regular inter-subjectivity checks. This time consuming process resulted in a substantial level of thoroughness. A distillation of major findings is presented here.

The TIES Reform Theory predicts certain outcomes that were addressed through specific interview questions. These outcomes included an understanding of the concepts of vision, innovation diffusion, the role of continuing professional leadership development, and TIES legacy.

When asked about a vision for IT, one CAO recognized that, overall, the university is "struggling" with determining how IT will be used in the future, but that possibly "that struggle is a good thing". In terms of the actual vision at the university, during the interviews both CAOs mentioned "alternative learning technologies as enhancing and expanding our presence, both in the geographic...and.program sense...there are a number of advanced areas, specialized areas, and cost-recovery areas where...the focus would be". One $\mathrm{CAO}$ suggested that the focus could be on asynchronous activities that are interactive with "post-degreed professionals".

In regards to the university's vision of the future use of IT, one CAO stated

the landscape is changing greatly but we are holding on to models, and I think all universities are trying to differentiate themselves. When I said that we're holding on to a face-toface model, however technologically enhanced, what we're really saying is we're betting the farm, so-to-speak,...that our approach is going to be good approach and...the future...best students (will) really want a face-to-face interaction, again with all the technology enhancements, a face-to-face interaction from somebody who's a leader in the field in research in the field and is ... at the leading edge in their field.

S/he went on to say

we've got a huge infrastructural investment, we've got huge intellectual capital investment in a lot of the models we've been used to for hundreds of years and it's a tough thing to think about, someone coming in with absolutely new approaches that, like (post-secondary institution that has all online courses)... that can simply say that we don't need any of that infrastructure, we don't need our instructional faculty or our instructional people to be world leading researchers, we just have to develop solid content...the whole concept of an institutional-specific degree is an interesting one that I think is being tested.

The theoretical importance of vision in promoting second-level innovation diffusion was not viewed with the same level of importance by senior administrators, who rely largely on administrative policy, procedures and committees to bring about first-level change. Nor is it viewed as important by faculty and department administrators, who seemed to [mis]interpret vision (where do we want to go as a faculty/department?) as strategy (how do we get there?). Subsequent to TIES, a draft vision statement was created, a statement which clearly indicates limits to the use of IT. The statement was not extensively vetted by administrators, and its chief architects have since moved on to different positions.

Another expectation derived from the TIES Reform Theory was that there would have been some recognition, on the part of faculty and administration participants, that IT diffusion is much more complex that effecting simple change; that is IT is a disruptive innovation and the characteristics of innovation diffusion must be incorporated into the reform process. Only two F/DA touched on the aspect of IT being an innovation. One F/DA identified that one aspect required for the adoption of innovation is that inside leaders must exist who will utilize new technologies and share that information with colleagues. Another 
F/DA suggested the following ways of facilitating the adoption of innovation: 1) ensure that people are informed, 2) generate excitement about the new technology in the faculty, and 3) seek wise adoption of the new technologies. Two FM acknowledged an aspect related to IT being an innovation through their statement that the main challenge they experienced related to the adoption of innovation, was resistance. They identified that some instructors have changed teaching styles and others have not. One FM indicated that some profs feel " 'I've been successful so why should I change' and not truly understanding the need to change...(that) we're going to serve a different market". Other than these comments, there was little acknowledgement that the diffusion of the IT innovation is unique and requires a specific approach for adoption to occur.

Neither administration nor faculty distinguished change from reform; the former exemplified by increased use of IT within the classroom; the latter by new instructional applications that supercede or extend the classroom. This is evidenced by the imprecise and mixed use of terms such as vision, goal, strategy, reform and change in interviewees' responses. Fundamental reform in the way individual, departments or the institution function was rarely discussed as an option. It may be hypothesized that one reason for limited diffusion of IT is that it is perceived as a minor, first-order change rather than as a disruptive, secondorder innovation.

The data from this research indicate that the leadership purpose of TIES were adequately communicated and interpreted by the participants. CAOs perceived the purpose of TIES to be an attempt to determine and develop resources/support for faculty members.

F/DA identified the purpose and goals of TIES to be: 1) "to encourage staff to use new learning technologies in their teaching and instruction"; 2) "to offer support, advice, and to encourage innovation"; 3) to encourage senior administration, by showing them the potential of LT, so that they would move to the adoption of new teaching technologies; 4) to facilitate senior administration's understand of some of the elements adherent to the process of transformation; 5) to build teams that would be facilitators when they returned to their units and lead the transformation of the faculty; 6) to encourage collegiality and raise awareness about what other departments were doing; and 7) to identify departments who had ongoing initiatives or wanted to begin initiatives.

FM responded that TIES' purpose and goals were: 1) to bring faculty members together to develop their own technology integration plan for their department by providing a framework and structure for doing this, 2) "to teach people that were learning about technologies", 3) to provide information so that the participants would teach others in the faculty/department, and 4) to create a core group of people interested in modern technologies so as to spread this interest to others in their faculty. Participants' reported experience of TIES supported these goals.

At all stakeholder levels, the benefits of participating in TIES far outweigh the drawbacks. Each participant realized some benefit, and each of these benefits has played a part in the process of how smoothly the adoption of specific innovations will occur within these faculties. How far the diffusion process has occurred would be difficult to determine without interviewing other non-participating faculty members.

\section{Conclusions and Discussion}

Reasons for the lack of strong vision development are only subject to speculation at this point. One possibility is that like most research universities whose stated goals are to promote research, teaching and service, the de facto emphasis is clearly on research (Aronowitz, 2000). While increasing involvement with IT for noble purposes such as increased achievement, attitudes and better access and learning efficiency is certainly a strong consideration, there are strong [er?] issues. Research, patents, corporations and other university spinoffs generate a significant amount of money, money that has become increasingly important because government funding has been significantly curtailed. It is likely that strong support for IT 
Educational Reform as Innovation Diffusion

will carry with it significant add-on costs, divert the effort to generate significant revenues from research endeavors, and not replace revenues with the limited income from instructional materials sold.

In this study, which formally began in 1996, (Szabo, 1996) the history of innovation diffusion was consulted in an effort to inform why the promised reforms of education with respect to IT have not materialized. Several characteristics of successful innovation diffusion and implications for reform through IT were identified. Based on these characteristics, a system to start a reform effort in a specific research university (TIES) was created and operated for one year. Follow up observations and interviews reveal a mixed set of results based on prior expectations. Suggestions for modifications to the system and procedures utilized are forthcoming.

The major conclusion from this exercise is that research-oriented universities can easily underestimate the magnitude of the disruptive, second-order reform nature of IT. Consequently, they are likely to apply inappropriate change strategies instead of looking to the guidance from the history of innovation diffusion.

\section{References}

Alexander, P, A., Murphy, P. K., \& Woods, B. S. (1996). Of squalls and fathoms: Navigating the seas of educational innovation. Educational Researcher, 25, 31-36.

Allen, D. (1992). Schools for a new century. NY: Praeger.

Anderson, R. E., and Becker, H. J. (2001). Teaching, learning, and computing: 1998 national survey. Report \# 8. Retrieved September 7, 2001, from http://www.crito.uci.edu/tlc/html/findings.html.

Antoine de Saint-Exupéry, 1979). The wisdom of the sands. Translated by S. Gilbert from the French Citadelle (University of Chicago Press, Chicago, 1979; reprint of the edition published by Harcourt, Brace, New York, 1950.

Aronowitz, S. (2000). The knowledge factory: Dismantling the corporate university and creating true higher learning. Boston: Beacon Press.

Coombs, P. W. (1985). The world crisis in Education: The view from the eighties. NY: Oxford University Press.

Crawford, C. B., \& Strohkirch, C. S. (1997). Influence methods and innovators: Technocrats and champions. The Journal of Leadership Studies, 4, 43-54.

Cuban, L. (1986). Teachers and machines, New York: Teachers College Press.

Cuban, L. (1996). Techno-reformers and classroom teachers. ERIC. Retrieved November 30, 2001, from http://www.edweek.org/ew/vol-16/06cuban.h16

David, P. A., \& Wright, G. (1999). Early twentieth century productivity growth dynamics: An inquiry into the economic history of "Our Ignorance". Discussion Papers in Economic and Social History. Oxford University. Retrieved November 30, 2001, from http://www.nuff.ox.ac.uk/Economics/History/.

Deal, T. E., Meyer, J. W. \& Scott, W. R. (1975). Organizational influences on educational innovation. In J. V. Baldridge \& T. E. Deal (Eds.) Managing Change in Educational Organizations, Berkeley, CA: McCutchan Publishing Corporation, 109132.

Degrees of Freedom, 1998 Supplement. (1998). Edmonton, AB: University of Alberta.

Dooley, K. E. (1999). Towards a holistic model for the diffusion of educational technologies: An integrative review of educational innovation studies. Educational Technology and Society, 2. Retrieved November 30, 2001, from

http://ifets.ieee.org/periodical/vol_4_99/kim_dooley.html

Etzioni, A. (1972). Human beings are not very easy to change after all. Saturday Review, 45-47.

Finn, C. E. (1991). We must take charge. NY: The Free Press.

Fullan, M. \& Stiegelbauer, S. (1991). The new meaning of educational change. $2^{\text {nd }}$ Ed. New York, NY: Teachers College Press.

Goodlad, J. I. (1984). A place called school: Prospects for the future. New York: McGraw-Hill 
Green, K. (2000). The 2000 national survey of information technology in US higher education. Encino, CA: Campus Computing. Retrieved November 30, 2001, from http://www.campuscomputing.net/summaries/2000/index.html.

Hughes, T. P. (2001). Through a glass darkly: Anticipating the future of technology-enabled education. Educause Review, 36, 16-26.

Jonassen, D. H. (1995). Supporting communities of learners with technology: A vision for integrating technology with learning in schools. Educational Technology, 5, 60-63.

Kotter, J. P. (1996). Leading change. Cambridge, MA: Harvard Business School Press.

Leithwood, K., \& Montgomery, D. (1982). The role of the elementary

Lewin, K. (1952). Group decision and social change. In E. Newcombe and R. Harley (Eds.), Readings in social psychology (pp. 459-473). New York, NY: Henry Holt.

Lockard, J., Abrams, P., \& Many, W. (1997). Microcomputers for twenty-first century educators (4 ${ }^{\text {th }}$ ed.). New York, NY: Longman.

Markus, M. L. (1990). Toward a "Critical Mass" theory of interactive media. Communication Research, 14, 491-511

Mitchell, J. M. (1992). The keys to successfully managing the change to open learning. Conference Proceedings of the ITTE Annual Meeting. Brisbane, Australia.

Moller, G. (1993). The consultant as organizational change agent. New Directions for Adult and Continuing Education, 58, 7379.

Morris, D. R. (1997). Adrift in the sea of innovations: A response to Alexander, Murphy and Woods. Educational Researcher, $26,22-26$.

Mosteller, F. (1981). Innovation and evaluation. Science, 211, 881-886.

Mullok, L. (2001). Understanding and changing your organization's culture. Industrial Management, 43, 18-24.

NCOEIE (1983). A nation at risk The imperative for educational reform: A report to the nation and Secretary of Education. Washington, DC: The National Commission on Excellence in Education.

Odomirok, P. (2001). The power of collaborative purpose. Industrial Management, 43, 28-33.

Office of Technology Assessment (1989). Linking for learning: A new course for education, (OTA Publication No. SET-430), Washington, DC: U.S. Government Printing Office.

Oliver, P., Marwell, G., \& Teixeira, R. (1985). A theory of critical mass: Interdependence, group heterogeneity, and the production of collective action. American Journal of Sociology, 91, 552-556.

Olsen, F. (2001). Survey finds another increase in campus spending on information technology. The Chronicle of Higher Education. Retrieved April 4, 2001, from http://www.chronicle.com/.

O'Neil, J. (1995). On technology and schools: A conversation with Chris Dede. Educational Leadership, 53, p 6-9.

Orlikowski, W. J. \& Hofman, J. D. (1997). An improvisational model for change management: The case of groupware technologies. Sloan Management Review, 39, 11-21.

Pinchot III, G. (1985). Intrapreneuring. New York, NY: Harper \& Row.

Postman, N. (1993). Technopoly: The Surrender of Culture to Technology. New York: Vintage Books.

Presseisen, B. Z. (1985). Unlearned lessons. Basingstoke: Falmer.

Rogers, E.M. (1983). Diffusion of Innovations (4th ed.), New York: The Free Press.

Rossman, G., Corbett, D., \& Firestone, W. (1988). Change and effectiveness in schools: A cultural perspective. Albany, NY: State University of New York Press.

Senge, P. M. (1990). The fifth discipline: The art and practice of the learning organization. New York, NY: Currency Doubleday.

Shalley, C. E. \& Perry-Smith, J. E. (2001). Effects of social-psychological factors on creative performance: The role of informational and controlling expected evaluation and modeling experience. Organizational Behavior and Human Decision Processes, 84, 1-22.

Sink, S., \& Morris, W. (1995). By what method?_Norcross, Georgia: Engineering and Management Press. 
Educational Reform as Innovation Diffusion

Smith, L. M., Prunty, J. P., Dwyer, D. C. and Kleine, P. F. (1987). The fate of an innovative school. Lewes: Falmer.

Snow, Charles P. (1961). Science and government. Cambridge, Mass.: Harvard University Press.

Spencer, D. A. (1996). Teachers and educational reform. Educational Researcher, 25, 15-17.

Straessens, K. (1991). The professional culture of innovating primary schools: Nine case studies. A paper presented at the annual meeting of the American Educational Research Association, April 3-7, 1991, Chicago.

Szabo, M. (1996, June). Change in the use of alternative delivery systems through professional development within colleges and universities, Paper presented at the annual meeting of Ed-Media/Ed-Telecomm 96. Boston, MA. Retrieved November 30, 2001, from http://www.quasar.ualberta.ca/IT/research/Szabo/Change.html

Szabo, M. (1998). Modules for the training, infrastructure and empowerment system. Retrieved November 30, 2001, from http://www.quasar.ualberta.ca/edmedia/TIES/Ties_home.html

Szabo, M. (2000). Survey of Instructional Technology Research or, If Instructional Technology Effectiveness Were a Crime, Would There Be Enough Evidence to Convict it? Retrieved November 30, 2001, from http://www.quasar.ualberta.ca/edmedia/readingsnc/Nrefsza.html

Szabo, M., Anderson, T., \& Fuchs, A. (1998). A Change System: The Training, Infrastructure and Empowerment System (TIES). Final Report to Alberta Advanced Education and Manpower: Learning Enhancement Envelope I. Retrieved November 30, 2001, from http://www.quasar.ualberta.ca/IT/research/Szabo/TIES_FinalReport.html

Thompson, R. (2001). Much tech spending a waste. (2001, October 25). The Financial Post, p. fp4.

Tyack, D., \& Cuban, L. (1995). Tinkering toward utopia: A century of public school reform. Cambridge, MA: Harvard University Press.

U.S. Department of Education. (2000). The power of the internet for learning: Moving from promise to practice. Retrieved March 13, 2002, from http://www.ed.gov/offices/AC/WBEC/FinalReport/

White, J. A. Integrating computers in education. (What's It Really Like Out There?). Retrieved October 2, 2001, from http://www.coedu.usf.edu/jwhite/eme2040/integrate2.html

\section{Biography}

Professor Szabo has been intensely involved in Instructional Technology since 1970 and has been intrigued by the slow uptake of reform in general and IT specifically by educators and educational administrators. He has conducted research and development projects for education commercial government and military training. He is extensively published and has consulted around the world on IT. More information is available from his CV http://www.quasar.ualberta.ca/DRMIKE.

The research and development reported here was supported in part by grants from the Office of Learning Technologies, Government of Canada and the Alberta Education and Career Development, Government of Alberta. 